\title{
Study on Development Status and Countermeasures of Cold Chain Logistics in Blue and Yellow Economic Zone
}

\author{
Changgang Xiao \\ Shandong Yingcai University, Ji'nan, 250104, China
}

Keywords: Blue and Yellow Economic Zone. Shandong. Logistics industry. Cold chain logistics

\begin{abstract}
The Blue and Yellow Economic Zone refers to intersection region of the Yellow River Delta High-efficiency Eco-economic Zone and the Blue Economic Zone of Shandong Peninsula, and has been promoted to the height of national strategy in the 12th Five-year Plan, making its overall development highly concerned by the society. As an important part of modern logistics, cold chain logistics plays an extremely important role in perfecting regional economic supply chain system and promoting overall development of regional logistics industry. To this end, economic development of the Blue and Yellow Economic Zone shall be fully supported by cold chain logistics. This paper begins with overview of the Blue and Yellow Economic Zone and cold chain logistics, and studies on development status and countermeasures of cold chain logistics in the Blue and Yellow Economic Zone.
\end{abstract}

\section{Overview of the Blue and Yellow Economic Zone and cold chain logistics}

\section{Overview of the Blue and Yellow Economic Zone}

The planned scope of the Blue and Yellow Economic Zone covers all sea area of Shandong Province, Yantai, Dongying, Qingdao, Weihai, Rizhao, Weifang cities, and land area of 2 coastal counties namely Wudi County and of Zhanhua County Binzhou City. The Blue and Yellow Economic Zone has been listed as a region in which the country will develop rigorously marine economy, and plays an important role in building a modern marine industry system and improving marine resources utilization efficiency; the planned scope of the Yellow River Delta High-efficiency Eco-economic Zone covers Historical Alluvial Plain of the Yellow River, coastal region of north Shandong and surrounding extension, specifically including 6 cities and 19 counties such as Binzhou City, Dongying City, Hanting District, Shouguang City, Dezhou Leling City, Changyi City and Qingyun County in north Weifang City, Laizhou City and Gaoqing County, and is an important region in which China develops high-efficiency eco-economy.

\section{Overview of cold chain logistics}

The so-called cold chain logistics specifically refers to a special supply chain system that keeps fresh products always in low-temperature environment during production, storage, transportation, sales and consumption from the supplying places to receiving places. Cold chain logistics shall follow strictly “3T" principles, namely Time, Temperature and Tolerance, in order to reduce loss of fresh products and guarantee the quality of fresh products. At current stage, products that China handles in cold chain logistics are divided into three categories: firstly, primary agricultural products, including fruit, vegetables, aquatic products, meat and poultry, flowers and plants, and eggs etc; secondly, processed good, including cooked food, cold drinks, quick-frozen food and dairy products etc; and thirdly, special drugs etc that must be of cold storage.

\section{Development status of cold chain logistics in the Blue and Yellow Economic Zone}

Development advantages of cold chain logistics in the Blue and Yellow Economic Zone Transportation system is being gradually perfected.

According to current situation, cold chain logistics industry in the Blue and Yellow Economic Zone has a good development prospect, and lays a good foundation for the development of this industry in terms of traffic conditions and logistics subjects. Since 2010, Shandong Province has 
invested a total of RMB 167.3 billion in construction of transportation infrastructure within 4 years, and focuses on implementing three major projects namely establishing large road network, building large ports and developing great logistics, and promotes vigorously the perfection of transportation system and rapid development of modern transportation industry.

\section{Logistics industry develops rapidly}

At present, Shandong has over 5,000 logistics enterprises, gradually forming a logistics enterprise group with industrial characteristics, which includes logistics enterprises with diverse forms of ownership, various service modes and different business scales. Among top 100 national logistics enterprises, 22 enterprises are from Shandong Province, such as Shandong Province Communication and Transportation Group, Haiers Logistics and China Post Logistics (Shandong Province) etc. Meanwhile, Korean Hanjin Shipping, Danish Maersk, FedEx and other international logistics companies also enter Shandong Province, with logistics business covering shipping, marine transportation, air transportation, containers and warehousing etc. As a result, Shandong logistics infrastructure begins to take shape, and thus provides important guarantee for the development of cold chain logistics in the Blue and Yellow Economic Zone.

\section{Development disadvantages of cold chain logistics in the Blue and Yellow Economic Zone Decentralized cold chain logistics resources}

Among Shandong enterprises which are included in the list of top 100 national logistics enterprises, only Shandong Rokin Logistics specializes in cold chain logistics business, and others have other business besides cold chain logistics business. On the whole, markets of cold chain logistics in the Blue and Yellow Economic Zone are less centralized with decentralized logistics resources, which are mainly reflected in the following two aspects: firstly, enterprises engaged in cold chain logistics business have current situations of small scales and large number, and most enterprises have registered capital of less than RMB 1 million, and thus it is difficult to form scale effects of cold chain logistics industry; secondly, logistics industry is unevenly distributed in the Blue and Yellow Economic Zone, mainly in Qingdao and Zibo etc, which have their respective planning of logistics industry and compete for logistics resources, and thus lead to more decentralized logistics resources of the Blue and Yellow Economic Zone, making it impossible to form a situation of powerful combination.

\section{Backward cold chain logistics service mode}

Logistics enterprises in the Blue and Yellow Economic Zone do not take cold chain logistics services as the key of enterprise development, and only several large-scale logistics enterprises have several hundred refrigerating vehicles, sound cold chain logistics network system and high-level automated information management system, while other small-scale logistics enterprises have not basically an information management system, but only several refrigerating vehicles and several short-distance transportation lines. Backward technical equipment and service management of cold chain logistics enterprises lead to poor overall strength of cold chain logistics enterprises in the Blue and Yellow Economic Zone. Meanwhile, in the Blue and Yellow Economic Zone, cold chain logistics enterprises have a single service mode, and lack additional services and value-added services. Most cold chain logistics enterprises mainly provide basic services such as warehousing, in-city delivery and cold chain transportation etc. Only large-scale cold chain logistics enterprises provide additional services of distribution, sorting and labeling etc, and even fewer cold chain logistics enterprises could provide value-added services such as purchasing, inventory management and data analysis etc. Restricted by business strength of cold chain logistics enterprises, current cold chain logistics enterprises in the Blue and Yellow Economic Zone are unable to provide high-end value-added services such as distribution processing, information processing and financial services etc.

\section{Non-standard cold chain logistics market}

At present, the Chinese government focuses on normal temperature logistics when formulating logistics industry planning, policies and systems, while ignoring the demands of regional economic development for cold chain logistics. As a result, there is a lack of cold chain logistics industrial standards, resulting in poor standardization of cold chain logistics market directly. In this case, cold 
chain logistics enterprises often participate in market competition by reducing prices at the expense of cold chain logistics service quality, and thus result in vicious market competition. In the Blue and Yellow Economic Zone in particular, most of the third-party cold chain logistics enterprises provide only refrigerating and transportation services, but have not a sound cold chain logistics service system. These enterprises often use price competition means, and thus can hardly obtain high profits, and have not enough capital to invest in fixed assets, expand logistics network and improve cold chain logistics service level. On this basis, some manufacturers in the Blue and Yellow Economic Zone are unwilling to outsource refrigerating logistics business, worrying that the quality of fresh products cannot be guaranteed during service of the third-party cold chain logistics enterprises. As a result, "quality" cannot be guaranteed and "quantity" is reduced during cold chain logistics operation, and thus cold chain logistics market has not a benign development trend.

\section{Poor performance of cold chain logistics industry}

Due to the influence of non-standard cold chain logistics market, small scale of logistics enterprises and poor strength of technical equipment, cold chain logistics industry in the Blue and Yellow Economic Zone has generally poor performance at present. Reasons of this situation mainly include the following three aspects: firstly, business of most logistics enterprises in this zone is confined to fixed regions, and is not expanded to surrounding regions, and thus there are few combination and acquisition of logistics enterprises, and cold chain logistics industrial cluster effects cannot be formed. Secondly, cold chain logistics market is unsaturated in this zone, there are a large number of small-scale cold chain logistics enterprises, which have great survival and development space, and thus it is unnecessary to increase market shares by acquisition and combination, but shall retain market competitiveness. Thirdly, some large-scale cold chain logistics enterprises in the Blue and Yellow Economic Zone are restructured from reform of state-owned enterprises, and thus their operation and management are subject to interference of local governments as enterprises are not completely separated from the government, making cold chain logistics industry have obvious local protection, and power combination is hindered among enterprises. Based on the above three points, cold chain logistics industrial cluster is of a low degree in the Blue and Yellow Economic Zone, which affects seriously performance improvement of cold chain logistics industry.

\section{Development countermeasures of cold chain logistics in the Blue and Yellow Economic Zone}

\section{Perfect cold chain logistics standards}

To change current backward development of cold chain logistics in the Blue and Yellow Economic Zone, China shall perfect cold chain logistics standards, and promote standardized and normalized operation of cold chain logistics operation, to provide powerful support for developing cold chain logistics industry. In recent years, the Ministry of Agriculture of PRC and the Ministry of Commerce of PRC etc have issued policies such as Packaging, Labeling, Transportation and Storage of Frozen Food, Requirement of Refrigerated Transportation of Perishable Foodstuff and Development Planning of Cold Chain Logistics of Agricultural Products etc, but there is still a lack of specific rigid documents and implementation standards in many fields of cold chain logistics, and no sound cold chain logistics standard system is formed. Thus, the Blue and Yellow Economic Zone shall combine national overall development planning of cold chain logistics, and formulate specific cold chain logistics industry service standards according to development characteristics and demands of cold chain logistics in this zone, such as cold chain logistics enterprise qualification certification standard, cold chain logistics enterprise integrity system standard, cold chain logistics industry service standard, cold chain logistics service acceptance standard, and cold chain logistics enterprise market access standard etc, unify technical parameters, standardize operation order of cold chain market, and promote standardized development of cold chain logistics industry in the Blue and Yellow Economic Zone.

\section{Accelerate the construction of cold chain logistics technical equipment}

The Blue and Yellow Economic Zone shall further strengthen the construction of cold chain logistics technical equipment, improve current situation of decentralized cold chain logistics 
resources and backward service mode, perfect cold chain logistics distribution facilities constantly, and improve cold chain logistics service quality. Firstly, it shall encourage cold chain logistics enterprises to purchase refrigerating transportation vehicles, build cold chain logistics distribution centers, and perfect cold chain logistics service system, in order to increase market shares with high-quality and high-efficiency cold chain transportation services, and promote the access of cold chain logistics market to a benign circle. Secondly, it shall encourage cold chain logistics enterprises to accelerate information construction, and introduce actively modern logistics technologies such as automatic identification, GPS transportation vehicle automatic temperature control system, EFT technology and EDI technology etc, to realize whole process information control of cold chain logistics business. Meanwhile, qualified cold chain logistics enterprises shall also attach importance to technological transformation and upgrading, introduce advanced technologies of warehouse management system, automated refrigerator technology, nondestructive examination, vacuum pre-cooling technology and commercialized processing technology etc, improve equipment and technology level, and lead to enhance overall strength of cold chain logistics industry.

\section{Develop vigorously the third-party cold chain logistics enterprises}

The third-party cold chain logistics enterprises are main driving forces of the development of cold chain logistics industry, and play an important role in overall service strength of cold chain logistics industry. Thus, the Blue and Yellow Economic Zone shall develop vigorously the third-party cold chain logistics, and use preferential policies to promote the third-party cold chain logistics enterprises to expand business scale constantly and enhance their ability to provide high-end logistics services. The third-party cold chain logistics enterprises shall attach importance to logistics facility construction, logistics talent training and logistics network building, and realize scale operation through powerful combination and complementary advantages, to meet high requirements of the Blue and Yellow Economic Zone for cold chain logistics service quality and improve their overall service ability. In addition, the Blue and Yellow Economic Zone shall also accelerate the integration of cold chain logistics, and form a complete industry chain of production, processing, sales, storage and transportation, in order to strengthen organization and management of the entire cold chain logistics system, make all cold chain logistics enterprises have common interests, and improve operation efficiency of cold chain logistics.

\section{Strengthen supervision of the government and all levels of competent departments}

The development of cold chain logistics in the Blue and Yellow Economic Zone cannot be separated from the support of the government and all levels of competent departments, and strengthened supervision of which is also required. Firstly, government departments shall formulate sound cold chain plans according to current situation of regional economic development and demands for cold chain logistics, and provide conditional financial support and preferential policy support for cold chain logistics enterprises according to plans, such as support in terms of construction of refrigeration houses, key technological transformation and refrigerating vehicles purchasing etc. Secondly, cold chain logistics alliance shall be established under the dominance of government departments combined with superior competent departments, industrial associations and logistics enterprises etc. This cold chain logistics alliance supervises cold chain logistics services, ensures implementation of policies, laws and regulations, documents and standards related to cold chain logistics, and includes cold chain logistics into the whole process of food circulation to be supervised.

\section{Conclusions}

In a word, cold chain logistics in the Blue and Yellow Economic Zone is still at the initial stage of development, and has deficiencies in technical equipment, service mode, market standardization and industrial performance etc, but still has good development prospect with sound transportation system and a huge number of logistics enterprises. Thus, the Blue and Yellow Economic Zone shall perfect cold chain logistics standard system, develop the third-party cold chain logistics enterprises, 
accelerate the construction of technical equipment and strengthen supervision of cold chain logistics etc, in order to promote actively sustainable and stable development of cold chain logistics industry.

\section{References}

[1] Hu Haiqing, Zhou Jing, Zheng Zhenzhen. Study on Optimization of Logistics Network Node in the Blue and Yellow Economic Zone [J]. Shandong Social Science. 2013 (2).

[2] Wang Xin. Analysis of the Current Situation of Logistics in the Economic Zone of Shandong Peninsula and Study on Integrated Development of Modern Logistics [J]. Jiangsu Commercial Forum, 2010 (4).

[3] Pang Shumei. Study on Regional Logistics Cooperation Based on the Blue Economic Zone of Shandong Peninsula [D]. Qufu Normal University. 2012.

[4] Wu Jiale, Kong Qingyuan, Zhu Fuqiang. China's Aquatic Products Cold Chain Logistics Development Planning of Numbers of Issues [J]. Refrigeration. 2008 (9).

[5] Qu Si, Wang Zhongwei. A Study on Cold Chain Logistics about Lively Aquatic Product in Poyang Lake Economic Region [J]. Commercial Times. 2011 (2).

[6] Liu Haidong, Cui Yahui. Study on the Development Status and Countermeasures of China's Cold Chain Logistics Industry [J]. Journal of Hubei Vocational College of Ecological Engineering. 2012 (9).

[7] Wang Shuai. Market Analysis of Aquatic Product Cold Chain Logistics in Qingdao City [D]. Ocean University of China. 2011. 